\title{
Abscission Agent Application and Canopy Shaker Frequency Effects on Mechanical Harvest Efficiency of Sweet Orange
}

\author{
Robert C. Ebel ${ }^{1,4}$ \\ University of Florida, IFAS, Southwest Florida Research and Education \\ Center, 2686 Highway 29 N., Immokalee, FL 34142
}

Jacqueline K. Burns ${ }^{2}$

Citrus Research and Education Center, 700 Experiment Station Road, Lake

Alfred, FL 33850

\author{
Kelly T. Morgan ${ }^{3}$ and Fritz Roka ${ }^{1}$ \\ University of Florida, IFAS, Southwest Florida Research and Education \\ Center, 2686 Highway 29 N., Immokalee, FL 34142
}

Additional index words. 5-chloro-3-methyl-4-nitro-1H-pyrazole, Hamlin, Valencia, citrus

\begin{abstract}
This study was conducted to determine the relationship of 5-chloro-3-methyl4-nitro-1H-pyrazole (CMNP) concentration and canopy shaker frequency on fruit detachment force, pre-harvest fruit drop, and mechanical harvesting fruit removal of 'Hamlin' and 'Valencia' sweet orange cultivars. CMNP was applied at 0,200 , and $300 \mathrm{mg} \cdot \mathrm{L}^{-1}$ in a carrier volume of $2806 \mathrm{~L} \cdot \mathrm{ha}^{-1}$. Four days after CMNP application, fruit were harvested with a canopy shaker that was operated at 3.0,3.7, and $4.3 \mathrm{~Hz}$ at a tractor speed of $1.6 \mathrm{~km} \cdot \mathrm{h}^{-1}$. The experiment was repeated $3 \times$ for 'Hamlin' (December, early January, and late January) and twice for 'Valencia' (March and April) during the 20082009 harvest season. Fruit detachment force was reduced by at least $50 \%$ for all CMNPtreated trees compared with the untreated controls at the time of harvest and was lower for $300 \mathrm{mg} \cdot \mathrm{L}^{-1}$ than $200 \mathrm{mg} \cdot \mathrm{L}^{-1}$ on three of the five dates tested. Pre-harvest fruit drop evaluated immediately before mechanical harvesting was higher for all CMNP-treated 'Hamlin' than untreated controls at all harvest dates, whereas $300 \mathrm{mg} \cdot \mathrm{L}^{-1}$ application resulted in higher pre-harvest fruit drop in 'Valencia' when compared with $200 \mathrm{mg} \cdot \mathrm{L}^{-1}$ or the untreated controls on both application dates. CMNP-induced fruit drop was higher in 'Hamlin' than 'Valencia'. CMNP had a greater effect on fruit removal at lower canopy shaker frequencies. The interaction of total fruit weight removed was not significant on any date as a result of variability among trees in the study. These data indicate that the amount of loosening by CMNP was concentration-dependent and facilitated removal, especially with lower canopy shaker frequencies. Development of viable commercial practices should use the percent of the total crop harvested and not the actual weight of fruit removed in determining efficacy of CMNP and harvest efficiency of the mechanical harvesters.
\end{abstract}

Of the 193,000 ha of sweet oranges [Citrus sinensis (L.) Osbeck] grown commercially for juice in Florida (Anonymous, 2008), 12,153 ha

Received for publication 15 Feb. 2010. Accepted for publication 1 June 2010.

This project was funded by UF/IFAS Citrus Initiative Funds.

We express their appreciation to Peter Newman and Luis Pozo for their technical assistance. We also express their appreciation to OXBO International Corp. for use and technical assistance with the multiple-fan sprayer and mechanical harvester. We thank AgroSource ${ }_{\mathrm{TM}}$ Inc. and the Harvest Council of the Florida Department of Citrus for their helpful advice and support.

${ }^{1}$ Associate Professor.

${ }^{2}$ Professor.

${ }^{3}$ Assistant Professor.

${ }^{4}$ To whom reprint requests should be addressed; e-mail rcebel@ufl.edu. branches. The percent of the total crop removed at any given time during the harvest period is a function of depth of placement of the shaker within the canopy, the frequency of shaking of each set of tines, tractor speed, and fruit detachment force (Whitney, 1997).

There are two kinds of canopy shakers currently used in the commercial citrus industry in Florida. "Pull-behind" canopy shakers are pulled behind a tractor and drop fruit to the ground (Whitney, 1997), which are picked up by hand laborers or pick-up machines (Bora et al., 2006; Hedden et al., 1983; Whitney, 1999). The self-propelled canopy shakers contain decks located horizontally under the shaker that can be moved perpendicular to the long axis of the machine and positioned under the canopy to catch fruit that drop during shaking. Self-propelled canopy shakers work in pairs on opposite sides of a tree row and position the decks under the tree until they meet. The two units move together down the tree row shaking both sides of each tree until the decks are full, at which point they stop and unload the fruit through a conveyor into the bed of a truck that remove the fruit from the grove.

There are no abscission agents that are currently registered for use on sweet oranges that would aid mechanical harvesting. An effective abscission agent would enhance predictability and removal of sweet oranges, which is currently a limitation of mechanical harvesters (Whitney, 1975, 2000, 2003; Whitney et al., 2000a, 2000b, 2001). An abscission agent would be especially useful during late-season harvesting of 'Valencia', in which mechanical harvesting has to be ended early as a result of excessive removal of the newly developing immature fruit (Burns et al., 2006b). Furthermore, an abscission agent would allow lower harvester settings that would presumably reduce canopy injury (Buker et al., 2004; Li and Syvertsen, 2004; Whitney, 2003). Canopy injury has led commercial growers to express concerns about long-term productivity, although research has shown that properly managed trees show no long-term reductions in yield or tree mortality (Hedden and Coppock, 1968; Li and Syvertsen, 2005; Li et al., 2006; Whitney et al., 1986; Yuan et al., 2005).

A commercial label for the abscission agent 5-chloro-3-methyl-4-nitro-1H-pyrazole (CMNP) is being actively pursued by the commercial citrus industry in Florida. CMNP has been shown to increase fruit removal and reduce the force necessary to remove the fruit (Burns et al., 2005; Ebel et al., 2009a, 2009b; Freeman and Sarooshi, 1976; Koo et al., 1999; Whitney, 1975, 1976; Whitney et al., 2000a, 2000b; Wilson, 1973). CMNP is currently being studied to understand factors that affect efficacy. Research has shown that CMNP efficacy is largely a function of concentration, coverage, post-spray precipitation, and air temperature (Alferez et al., 2005; BenSalem et al., 2001; Burns et al., 2006a; Ebel and Burns, 2008; Farooq et al., 2003; Kender and Hartmond, 1999; Koo et al., 1999, 2000; Salyani et al., 2002). CMNP efficacy is 
especially sensitive to temperature, with $15.6{ }^{\circ} \mathrm{C}$ considered a critical minimum (Ebel and Burns, 2008; Yuan and Burns, 2004).

This study was conducted to determine the relationship of CMNP concentration and cycling frequency of canopy shakers on harvest efficiency of 'Hamlin' and 'Valencia' sweet orange. The study was conducted on multiple dates for each cultivar but with climate conditions and CMNP application and canopy shaker frequency treatments standardized.

\section{Materials and Methods}

Plant material and culture. Five trials were conducted on fully mature, sweet orange [Citrus sinensis (L.) Osbeck] trees during the 2008-2009 harvest season. The trials were conducted in commercial groves that used standard cultural practices. Cultivar, rootstock, grove location, soil type, and spray dates varied for the five trials (Table 1). The study was conducted in the Flatwoods region of southern Florida. Citrus trees in this region are generally shallow-rooted $(\approx 45 \mathrm{~cm})$ as a result of root pruning by flooding during the rainy season (mid-May to mid-October). The dry season requires daily irrigation, which is usually provided by microsprinkler irrigation.

Treatments. Trees were sprayed with a multihead air-blast sprayer (model T1000; OXBO International, Clear Lake, WI), a vertical $5.5-\mathrm{m}$ boom oriented parallel to and arched over the outer part of the canopy (Ebel et al., 2009a, 2009b). Each boom had six equally spaced fan/nozzle assemblies and each fan assembly had eight Conejet \#12 nozzles (Spraying Systems Col., Wheaton, IL) operating at $16.2 \mathrm{MPa} \cdot \mathrm{cm}^{-2}$. The tractor speed during application was $1.6 \mathrm{~km} \cdot \mathrm{h}^{-1}$. The sprayer was calibrated immediately before CMNP application for every trial. CMNP (17\% a.i.) was applied at 0,200 , and $300 \mathrm{mg} \cdot \mathrm{L}^{-1}$ in a volume of $2806 \mathrm{~L} \cdot \mathrm{ha}^{-1}$ with $0.55 \mathrm{mg} \cdot \mathrm{L}^{-1}$ of the adjuvant Activator 90 (alkylphenol ethoxylate, alcohol ethoxylate, and tall oil fatty acid; Loveland Products, Inc., Greeley, CO). Dates for applications were made based on air temperatures being generally above $15.6{ }^{\circ} \mathrm{C}$ and no precipitation forecasted for the first $24 \mathrm{~h}$ after application, the critical time period in which efficacy has been shown to be affected (Kossuth et al., 1978). All sprays occurred between 1300 and $1600 \mathrm{HR}$.

Four d after CMNP application, the trees in each trial were mechanically harvested using a pull-behind canopy shaker (model 3210; OXBO International). The shaker cycle frequencies used were $3.0,3.7$, and $4.3 \mathrm{~Hz}$. The tractor speed during harvest was $1.6 \mathrm{~km} \cdot \mathrm{h}^{-1}$.

Data collected. Before harvest, fruit detachment force (FDF) was determined from 10 randomly selected fruit per plot. FDF was measured using a force gauge (Force One digital force gauge; Wagner Instruments, Greenwich, CT) as described previously (Pozo et al., 2004).

Fruit beneath each tree (pre-harvest fruit drop) were collected and the total weight determined. Fruit harvested by machine were collected into commercial bins that held $\approx 450 \mathrm{~kg}$ of fruit and weighed on a $5.6-\mathrm{t}$ capacity, $1.2 \times 1.2-\mathrm{m}$ electronic floor scale (Gator Deck; Avery Weigh-Tronix, Livonia, MI). Fruit remaining in the canopy after shaking were removed by hand and weighed.

Total yield was determined by adding the weights of the pre-harvest drop fruit, the fruit dropped to the ground by the mechanical harvester, and the fruit gleaned. The percent removed was the sum of pre-harvest fruit drop and mechanically harvested fruit.

Statistical analysis. All trials were conducted as a randomized complete block design with four blocks and three adjacent trees per plot. There were at least two buffer trees between plots and a buffer row between treatment rows. Within each block was a split plot with canopy shaker setting as the main plot and CMNP treatment as the split plot. Data were analyzed using the General Linear Models procedure of the Statistical Analysis System (SAS Institute Inc., Cary, NC). Where interactions were not significant, means were separated using Duncan's multiple range test. Because FDF and the percent of total yield that dropped to the ground occurred before the trees were harvested, these data were analyzed as a randomized complete block design with 12 blocks.

\section{Results and Discussion}

CMNP application dates were chosen using weather forecasts that predicted air temperature would be above $15.6^{\circ} \mathrm{C}$ and no precipitation forecasted for the first $24 \mathrm{~h}$ after application; nevertheless, air temperature dipped slightly below $15.6^{\circ} \mathrm{C}$ at night during the first four trials (Fig. 1). Air temperature is going to be a major consideration in scheduling commercial CMNP applications because temperatures often fall below $15.6{ }^{\circ} \mathrm{C}$ during winter (Fig. 2), the temperature below which fruit loosening slows (Yuan and Burns, 2004). Modeling the interaction of temperature and CMNP application on the rate of loosening would enhance scheduling of mechanical harvesting (Ebel and Burns, 2008).

FDF on the day of harvest was reduced by at least $50 \%$ in all trials with the reduction significantly greater at $300 \mathrm{mg} \cdot \mathrm{L}^{-1}$ than 200 $\mathrm{mg} \cdot \mathrm{L}^{-1}$ on three of the five dates (Fig. 3). For the 'Hamlin' trials, FDF of the controls was $\approx 65 \mathrm{~N}$ for the December and early January trial but $39 \mathrm{~N}$ for the late January harvest, indicating that natural loosening would have to be considered for optimizing CMNP applications. FDF of the controls was close to $80 \mathrm{~N}$ for both 'Valencia' trials. The difference in FDF between these two cultivars suggests that 'Hamlin' would be more efficiently removed at a given CMNP concentration than 'Valencia'.

$\mathrm{CMNP}$ at $300 \mathrm{mg} \cdot \mathrm{L}^{-1}$ increased pre-harvest fruit drop compared with the controls in all trials (Fig. 4). Pre-harvest fruit drop was higher after treatment with CMNP at 200 $\mathrm{mg} \cdot \mathrm{L}^{-1}$ compared with the controls in only the 'Hamlin' trials. CMNP promoted higher fruit drop in 'Hamlin' in the late January trial compared with the earlier trials as a result of over-maturation that led to lower FDF. These results demonstrate the importance of knowing the relative state of maturation as shown by FDF in determining CMNP concentration to apply.

Table 1. Cultivar, rootstock, grove, and environmental conditions during spray application of CMNP for each trial.

\begin{tabular}{|c|c|c|c|c|c|c|c|c|c|c|}
\hline \multicolumn{6}{|c|}{ Tree characteristics } & \multirow[b]{2}{*}{ Trial location } & \multirow[b]{2}{*}{ Soil classification } & \multicolumn{3}{|c|}{ Spray information } \\
\hline Cultivar & Rootstock ${ }^{z}$ & $\begin{array}{l}\text { Spacing } \\
(\mathrm{m})\end{array}$ & $\begin{array}{c}\text { Age } \\
\text { (years) }\end{array}$ & $\begin{array}{l}\mathrm{Ht} \\
(\mathrm{m})\end{array}$ & $\begin{array}{c}\text { Skirt }^{y} \\
(\mathrm{~m})\end{array}$ & & & $\begin{array}{c}\text { Date of } \\
\text { application }\end{array}$ & $\begin{array}{l}\text { Air temperature } \\
\left({ }^{\circ} \mathrm{C}\right)\end{array}$ & $\begin{array}{l}\text { RH } \\
(\%)\end{array}$ \\
\hline \multirow[t]{2}{*}{ Hamlin } & $\begin{array}{l}\text { Carrizo } \\
\text { citrange }\end{array}$ & $3.7 \times 7.8$ & 21 & 4.6 & 0.5 & $\begin{array}{l}\text { Lat. } 26^{\circ} 20^{\prime \prime} 05^{\prime} \mathrm{N} \\
\text { Long. } 81^{\circ} 22^{\prime \prime} 22^{\prime} \mathrm{W}\end{array}$ & $\begin{array}{l}\text { Immokalee fine sand (siliceous, } \\
\text { hyperthermic Arenic Alaquods) }\end{array}$ & 8 Dec. 2008 & $22.7-28.7$ & $49-51$ \\
\hline & $\begin{array}{l}\text { Swingle } \\
\text { citrumelo }\end{array}$ & $3.4 \times 6.7$ & 17 & 4.0 & 1.0 & $\begin{array}{l}\text { Lat. } 26^{\circ} 23^{\prime \prime} 15^{\prime} \mathrm{N} \\
\text { Long. } 81^{\circ} 23^{\prime \prime} 49^{\prime} \mathrm{W}\end{array}$ & $\begin{array}{l}\text { Ft. Drum (siliceous, hyperthermic } \\
\text { Aeric Endoaquepts) and Malabar } \\
\text { Fine Sand (siliceous, hyperthermic } \\
\text { Grossarenic Endoaqualfs) }\end{array}$ & 5 Jan. 2009 & $26.5-29.2$ & $54-60$ \\
\hline \multirow[t]{2}{*}{ Valencia } & $\begin{array}{l}\text { Carrizo } \\
\quad \text { citrange }\end{array}$ & $3.7 \times 7.6$ & 21 & 5.1 & 0.4 & $\begin{array}{l}\text { Lat. } 26^{\circ} 19^{\prime \prime} 39^{\prime} \mathrm{N} \\
\text { Long. } 81^{\circ} 22^{\prime \prime} 10^{\prime} \mathrm{W}\end{array}$ & $\begin{array}{l}\text { Wabasso fine sand (siliceous, active, } \\
\text { hyperthermic Alfic Alaquods) }\end{array}$ & 20 Mar. 2009 & $25.6-28.7$ & $39-48$ \\
\hline & $\begin{array}{l}\text { Carrizo } \\
\text { citrange }\end{array}$ & $3.7 \times 7.6$ & 21 & 4.7 & 0.4 & $\begin{array}{l}\text { Lat. } 26^{\circ} 19^{\prime \prime} 39^{\prime} \mathrm{N} \\
\text { Long. } 81^{\circ} 22^{\prime \prime} 10^{\prime} \mathrm{W}\end{array}$ & $\begin{array}{l}\text { Wabasso fine sand (siliceous, active, } \\
\text { hyperthermic Alfic Alaquods) }\end{array}$ & 14 Apr. 2009 & $27.5-31.7$ & $41-60$ \\
\hline
\end{tabular}

${ }^{\mathrm{z}}$ Carrizo citrange [C. sinensis $\times$ Poncirus trifoliata (L.) Raf.], Swingle citrumelo (Citrus paradisi $\times$ Poncirus trifoliata).

${ }^{\mathrm{y}} \mathrm{Height}$ of the lowest branches from the soil line.

$\mathrm{RH}=$ relative humidity. 


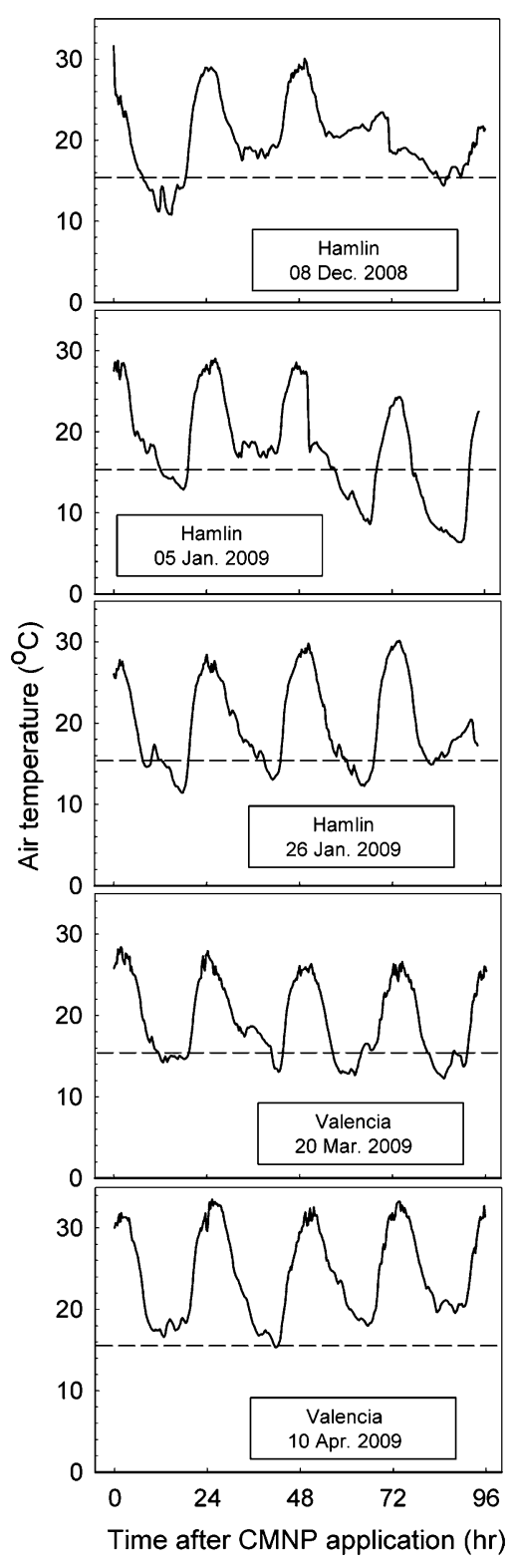

Fig. 1. Air temperature from the time of application through harvest for the five trials conducted in this study. The horizontal line at $15.6{ }^{\circ} \mathrm{C}$ indicates the temperature below which the rate of loosening by CMNP declines resulting from low air temperature.

Fruit drop is a minor concern with pullbehind canopy shakers because the sweepers in front of the tires reduce the number of fruit that get crushed, and all fruit ends up being picked up manually whether they drop naturally or are harvested by the machine. On the other hand, pre-harvest fruit drop is a major concern with self-propelled machines because its efficiency relies on fruit capture on the catch frame and thus minimizing the requirement for hand labor. Because the shaking mechanism of both types of machines is the same, the data in this study can be extended to self-propelled machines. For self-propelled machines, it would be most desirable to mechanically harvest before significant drop occurs. In this study, the greater drop for 'Hamlin' than 'Valencia'

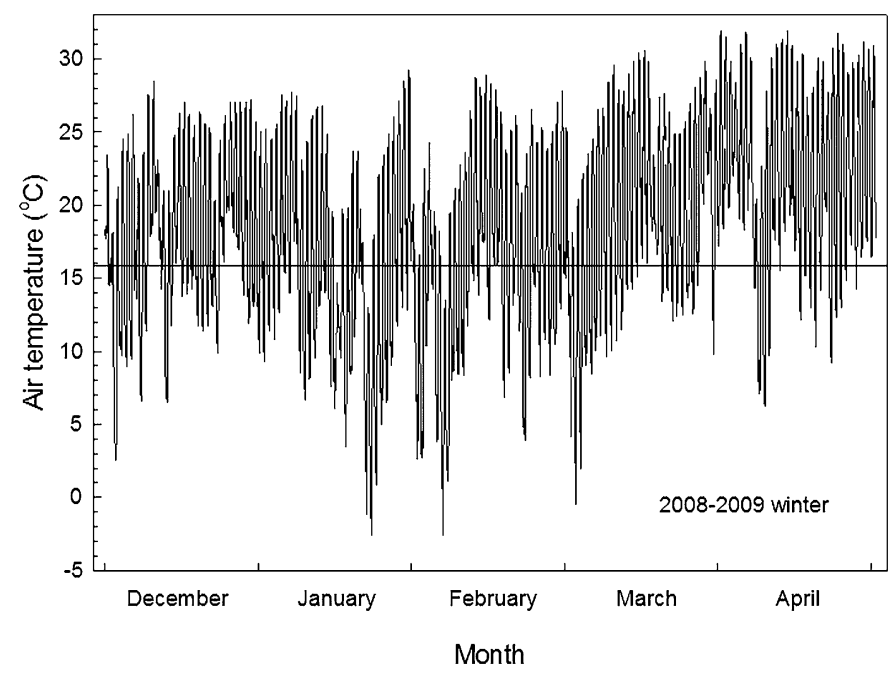

Fig. 2. Air temperature from 1 Dec. through 30 Apr. during the 2008-2009 winter. Air temperature was measured every $5 \mathrm{~s}$ at $2-\mathrm{m}$ height and the average across every $15 \mathrm{~min}$ was stored by a weather station in Immokalee, FL (Florida Agricultural Weather Network). The horizontal line at $15.6{ }^{\circ} \mathrm{C}$ indicates the temperature below which fruit loosening by CMNP is inhibited.

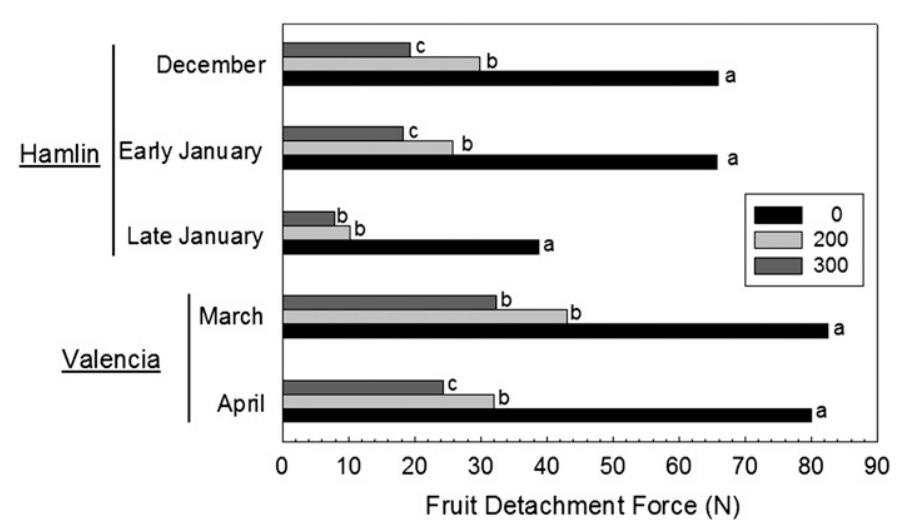

Fig. 3. Fruit detachment force four days after spraying with CMNP at 0,200 , and $300 \mathrm{~L} \cdot \mathrm{ha}^{-1}$ and immediately before harvesting with a canopy shaker. Different letters within each sampling date indicate significant differences $(P<0.05)$.

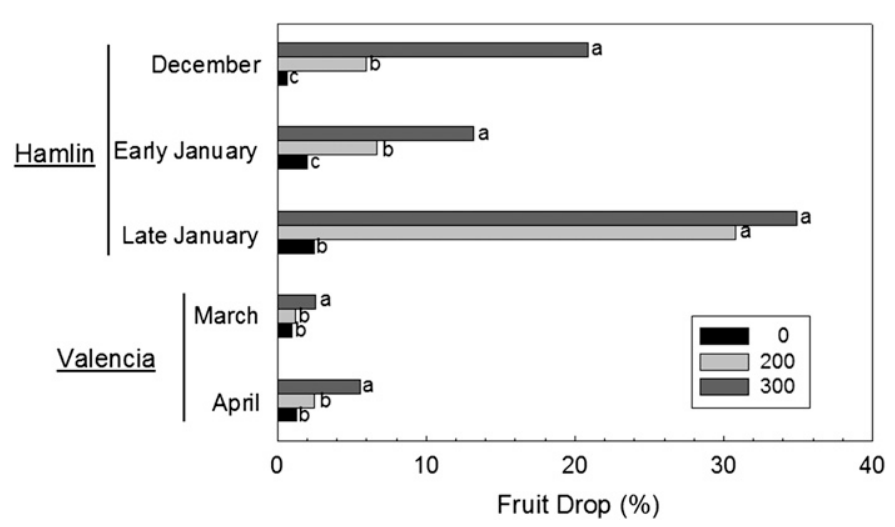

Fig. 4. Pre-harvest fruit drop percentage four days after CMNP application at 0,200 , and $300 \mathrm{mg} \cdot \mathrm{L}^{-1}$ and before harvesting with a canopy shaker. Different letters within each sampling date indicate significant differences $(P<0.05)$.

would indicate that waiting $4 \mathrm{~d}$ after spray application under the conditions CMNP was applied in this study would be too long for self-propelled machines. However, drop for 'Valencia' was under 6\% for all treatments, indicating that waiting $4 \mathrm{~d}$ after spray may be closer to the desired time for this cultivar for March and April assuming similar temperature conditions as in this study. More work must be done to identify application 
Table 2. Statistical analysis $(P>F)$ of machine harvest (canopy shaker) frequency and CMNP application on percent fruit removal (pre-harvest drop plus fruit removed by the canopy shaker) for each trial. ${ }^{\mathrm{z}}$

\begin{tabular}{|c|c|c|c|c|c|}
\hline \multirow[b]{2}{*}{ Significance } & \multicolumn{3}{|c|}{ Hamlin } & \multicolumn{2}{|c|}{ Valencia } \\
\hline & December & Early January & Late January & March & April \\
\hline Harvester $\times$ CMNP & $<0.0001$ & 0.0001 & $<0.0001$ & 0.0213 & 0.0951 \\
\hline CMNP & $<0.0001$ & $<0.0001$ & $<0.0001$ & $<0.0001$ & $<0.0001$ \\
\hline Harvester $\times$ block & 0.0047 & 0.0085 & 0.0889 & 0.1667 & 0.4187 \\
\hline Harvester & 0.0005 & 0.0078 & 0.0047 & 0.0003 & 0.0003 \\
\hline Block & 0.2796 & 0.7008 & 0.8871 & 0.8501 & 0.1236 \\
\hline
\end{tabular}

${ }^{z}$ The harvester term reflects different tine frequencies used during fruit harvesting $(3.0,3.7$, and 4.3 Hz), whereas the CMNP term reflects different a.i. concentrations applied $\left(0,200\right.$, and $\left.300 \mathrm{mg} \cdot \mathrm{L}^{-1}\right)$.

Table 3. Statistical analysis $(P>F)$ of fruit weight $(\mathrm{kg})$ removed by CMNP and mechanical harvester (canopy shaker) frequency treatments with removal including pre-harvest fruit drop plus fruit harvested by the canopy shaker.

\begin{tabular}{|c|c|c|c|c|c|}
\hline \multirow[b]{2}{*}{ Significance } & \multicolumn{3}{|c|}{ Hamlin } & \multicolumn{2}{|c|}{ Valencia } \\
\hline & December & Early January & $\overline{\text { Late January }}$ & March & April \\
\hline Harvester $\times$ CMNP & 0.8072 & 0.1433 & 0.6588 & 0.3748 & 0.6727 \\
\hline CMNP & 0.1123 & 0.0653 & 0.5584 & 0.0165 & 0.0198 \\
\hline Harvester $\times$ block & 0.8072 & 0.0717 & 0.0305 & 0.7197 & 0.6727 \\
\hline Harvester & 0.1919 & 0.9232 & 0.1590 & 0.0002 & 0.0180 \\
\hline Block & 0.2823 & 0.3986 & 0.7446 & 0.3224 & 0.0735 \\
\hline \multicolumn{6}{|l|}{ Main effect means } \\
\hline \multicolumn{6}{|l|}{ CMNP $\left(\mathrm{mg} \cdot \mathrm{L}^{-1}\right)$} \\
\hline 0 & $218 \mathrm{~b}$ & $108 \mathrm{ab}$ & 118 & $94 \mathrm{~b}$ & $100 \mathrm{~b}$ \\
\hline 200 & $236 \mathrm{ab}$ & $119 \mathrm{a}$ & 126 & $106 \mathrm{ab}$ & $119 \mathrm{a}$ \\
\hline 300 & $257 \mathrm{a}$ & $105 \mathrm{~b}$ & 119 & $115 \mathrm{a}$ & $116 \mathrm{a}$ \\
\hline \multicolumn{6}{|c|}{ Harvester frequency $(\mathrm{Hz})$} \\
\hline 3.0 & 218 & 110 & 103 & $77 \mathrm{c}$ & $95 \mathrm{a}$ \\
\hline 3.7 & 246 & 110 & 132 & $111 \mathrm{~b}$ & $114 \mathrm{a}$ \\
\hline 4.3 & 248 & 113 & 128 & $126 \mathrm{a}$ & $125 \mathrm{a}$ \\
\hline
\end{tabular}

Different letters within columns and main effect means indicate significance at $P<0.05$.

conditions that would enable maximum machine removal with minimal loss of fruit to pre-harvest drop.

For all trials, the percent fruit removal was calculated based on the weight of preharvest drop fruit plus the weight of fruit removed by the pull-behind canopy harvest machine. In cases in which CMNP was applied, the percent fruit removal reflected the weight of fruit removed by the interaction of CMNP and the harvest machine. There were significant interactions between CMNP concentration and canopy shaker frequency $(P<0.05)$, although the interaction was significant at the $P=0.0951$ for the April 'Valencia' trial (Table 2). The beneficial effects of CMNP were greater at lower canopy shaker frequency in all trials (Fig. 5), results of which are supported by an earlier study (Burns et al., 2005). The fruit remaining in the tree after machine harvest was generally closer to the trunk than the periphery and higher in the canopy (Burns et al., 2006; data not shown). The 12 sets of tines span a total of $3.5 \mathrm{~m}$ along the vertical axis, yet the distance between the skirt and highest part of the tree was as much as $4.7 \mathrm{~m}$. Although the tines did not reach the entire canopy, most fruit near the top and the bottom of the canopy were still removed as a result of the harvesting action promoted by canopy agitation. These trees were fully mature and the height typical of trees in the citrus industry in Florida.

In the current study, trees were selected based on their uniformity within the grove. Even with this intentional uniformity, the variation was such that the interaction between CMNP and harvester frequency on the actual weight of fruit removed was not significant in any trial, even at the $P<0.1$ level of significance (Table 3). Furthermore, the CMNP main effect was only significant for the early January 'Hamlin' trial $(P=$ 0.0653 ) and both 'Valencia' trials, which were $P=0.0165$ and $P=0.0198$ for the March and April trials, respectively. In general, trees sprayed with higher CMNP concentrations had higher fruit removal. Harvester frequency main effect was also only significant for the 'Valencia' trials with $P=0.0002$ and $P=0.0180$ for the March and April trials, respectively. In general, higher harvester frequency removed more fruit, but the differences between CMNP-treated and untreated fruit removal was less as shaker frequency increased (Fig. 5).

A commercial label is being actively pursued for CMNP as an aid to mechanical harvesting of sweet oranges in Florida. Assuming successful registration, it is our goal to establish protocols for CMNP adoption by the Florida citrus industry. The data in this study provide a framework by how much CMNP will improve harvest efficiency for 'Hamlin' and 'Valencia' from December through April. The data have direct application to pull-behind canopy shakers, but the pre-harvest drop of 'Hamlin' was excessive for self-propelled machines. Additional work needs to be conducted to determine the interaction of CMNP application and mechanical harvester on percent fruit drop and removal over time to optimize harvest efficiency.

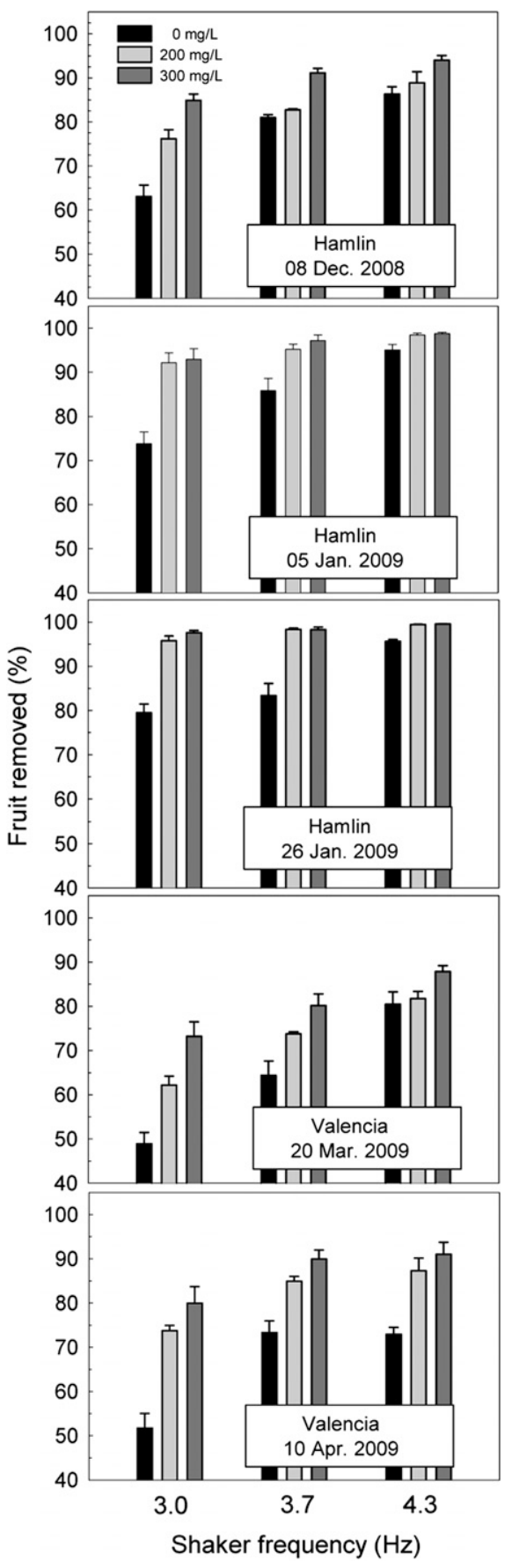

Fig. 5. Interaction of CMNP treatment and canopy shaker frequency on the percent of total yield removed on five different dates for 'Hamlin' and 'Valencia' sweet orange. Vertical bars are $2 \times$ the SE of the mean.

\section{Literature Cited}

Alferez, F., S. Shila, A.L. Umback, B. Hockema, and J.K. Burns. 2005. Citrus abscission and Arabidopsis plant decline in response to 5-chloro-3-methyl-4-nitro- $1 \mathrm{H}$-pyrazole are mediated by lipid signaling. Plant Cell Environ. 28:1436-1449.

Anonymous. 2008. Citrus summary, 2006-2007. Florida Agricultural Statistics Service, Fla. Dept. Agric. Consumer Services, Tallahassee, FL.

BenSalem, E., M. Sayani, and J.D. Whitney. 2001. Spray variable effects on deposition and harvesting efficacy of CMN-pyrazole. Proc. Fla. State Hort. Soc. 114:111-118. 
Bora, G., R.M. Ehsani, R. Goodrich, and G. Michaels. 2006. Field evaluation of a citrus fruit pick-up machine. Amer. Soc. Agr. Bio. Eng., paper \#061141. p. 1-10.

Buker, R.S., J.P. Syvertsen, J.K. Burns, F.M. Roka, W.M. Miller, M. Salyani, and G.K. Brown. 2004. Mechanical harvesting and tree health. Electronic Data Information Source, Institute of Food and Agricultural Sciences, University of Florida. Publication \#HS961.

Burns, J.K., R.S. Buker, III and F.M. Roka. 2005. Mechanical harvesting capacity in sweet orange is increased with an abscission agent. HortTechnology 15:758-765.

Burns, J.K., L. Pozo, K. Morgan, and F. Roka. 2006a. Better spray coverage can improve efficacy of abscission sprays for mechanically harvested oranges. Proc. Fla. State Hort. Soc. 119:190-194.

Burns, J.K., F.M. Roka, K.T. Li, L.V. Pozo, and R.S. Buker, III. 2006b. Late-season 'Valencia' orange mechanical harvesting with an abscission agent and low-frequency harvesting. HortScience 49:341-346.

Ebel, R.C. and J.K. Burns. 2008. Incorporation of air temperature into a model that predicts loosening of sweet oranges by CMNP. Fla. State Hort. Soc. Proc. 121:160-163.

Ebel, R.C., J.K. Burns, and K. Morgan. 2009a. Spray volume distribution and effect of 5chloro-3-methyl-4-nitro-1H-pyrazole for loosening sweet oranges using a vertical, multiple fan. HortScience 44:1895-1899.

Ebel, R.C., J. Burns, K. Morgan, and F. Roka 2009b. Interaction of CMNP concentration and canopy shaker setting on fruit removal of sweet orange. Fla. State Hort. Soc. Proc. 122:132135.

Farooq, M., M. Saylani, and J.D. Whitney. 2003. Effect of application techniques on abscission chemical deposition and mechanical harvesting of 'Valencia' oranges. HortTechnology 13:344 350 .

Florida Department of Citrus. 2008. 13 Feb. 2010. $<$ http://citrusmh.ifas.ufl.edu/index.asp? $=2 \& \mathrm{p}=2>$.

Freeman, B. and R.A. Sarooshi. 1976. Abscission chemicals for Valencia oranges in New South Wales. Aust. J. Exp. Agr. Anim. Husb. 16:943949 .
Hedden, S.L. and G.E. Coppock. 1968. Effects of the tree shaker harvest system on subsequent citrus yields. Proc. Fla. State Hort. Soc. 81:4852.

Hedden, S.L., G.E. Coppock, and J.D. Whitney. 1983. Citrus harvest mechanization in FloridaCurrent situation. Trans. Amer. Soc. Agr. Eng. 397-398.

Kender, W.J. and U. Hartmond. 1999. Variability in detachment force and other properties of fruit within orange tree canopies. Fruit Var. J. 53:105-109.

Koo, Y.M., M. Salyani, and J.D. Whitney. 1999. Effects of abscission chemical spray deposition on mechanical harvest efficacy of 'Hamlin' orange. Proc. Fla. State Hort. Soc. 112:28-33.

Koo, Y.M., M. Salyani, and J.D. Whitney. 2000 Spray variable effects on abscission of orange fruit for mechanical harvesting. Trans. Amer. Soc. Agr. Eng. 43:1067-1073.

Kossuth, S.V., R.H. Biggs, and V.M. Winkler. 1978. Uptake and distribution of 14C-labelled 5-chloro3-methyl-4-nitro-1H-pyrazoe in 'Valencia' and 'Hamlin' oranges. J. Amer. Soc. Hort. Sci. 103:20-22.

Li, K.T. and J.P. Syvertsen. 2004. Does mechanical harvesting hurt your trees? Citrus Industry $85: 30-33$.

Li, K.T. and J.P. Syvertsen. 2005. Mechanical harvesting has little effect on water status and leaf gas exchange in citrus trees. J. Amer. Soc. Hort. Sci. 130:661-666.

Li, K.T., J.P. Syvertsen, and J. Dunlop. 2006. Defoliation after harvest with a trunk shaker does not affect canopy light interception in orange trees. Proc. Fla. State Hort. Soc. 119:187-189.

Pozo, L., R. Yuan, I. Kostenyuk, F. Alferez, G.Y. Zhong, and J.K. Burns. 2004. Differential effects of 1-methylcycopropene on citrus leaf and mature fruit abscission. J. Amer. Soc. Hort. Sci. 129:473-478.

Salyani, M., E. BenSalem, and J.D. Whitney. 2002. Spray deposition and abscission efficacy of CMN-Pyrazole in mechanical harvesting of Valencia orange. Trans. Amer. Soc. Agr. Eng. 45:265-271.

Whitney, J.D. 1975. Orange yield and removal studies with air and trunk shakers using two abscission chemicals. Proc. Fla. State Hort. Soc. 88:120-124.

Whitney, J.D. 1976. Air shaker harvest trials in 'Valencia' oranges with two rates of abscission chemical. Proc. Fla. State Hort. Soc. 89:41-43.

Whitney, J.D. 1997. Field test results with mechanical citrus fruit removal devices. Proc. Fla. State Hort. Soc. 110:89-92.

Whitney, J.D. 1999. Field test results with mechanical harvesting equipment in Florida oranges. Appl. Eng. Agr. 15:205-210.

Whitney, J.D. 2000. Performance of mechanical citrus harvesters in Florida. Proc. Intl. Soc. Citricul. IX Congr. p. 277-279.

Whitney, J.D. 2003. Trunk shaker and abscission chemical effects on yields, fruit removal, and growth of orange trees. Proc. Fla. State Hort. Soc. 116:230-235.

Whitney, J.D., E. BenSalem, and M. Salyani. 2001. The effect of trunk shaker patterns on Florida orange removal. Appl. Eng. Agr. 17:461-464.

Whitney, J.D., D.B. Churchill, and S.L. Hedden. 1986. A five-year study of orange removal with trunk shakers. Proc. Fla. State Hort. Soc. 99: 40-44.

Whitney, J.D., U. Hartmond, W.J. Kender, J.K Burns, and M. Salyani. 2000a. Orange removal with trunk shakers and abscission chemicals. Appl. Eng. Agr. 16:367-371.

Whitney, J.D., U. Hartmond, W.J. Kender, M. Salyani, and J.K. Burns. 2000b. Abscission chemicals affect trunk shaker orange removal. Proc. Fla. State Hort. Soc. 113:93-96.

Whitney, J.D. and S.L. Hedden. 1973. Harvesting Valencia oranges with a vertical foliage shaker. Proc. Fla. State Hort. Soc. 86:41-48.

Wilson, W.C. 1973. A comparison of cycloheximide with a new abscission chemical. Florida State Hort. Soc. 86:56-60.

Yuan, R., F. Alferez, I. Kostenyuk, S. Singh, J.P Syvertsen, and J.K. Burns. 2005. Partial defoliation can decrease average leaf size but has little effect on orange tree growth, fruit yield and juice quality. HortScience 40:2011-2015.

Yuan, R. and J.K. Burns. 2004. Temperature factor affecting the abscission response of mature fruit and leaves to CMNP-pyrazole and ethephon in 'Hamlin' orange. J. Amer. Soc. Hort. Sci. 129:287-293. 